\title{
Reduction of Ecological and Economic Risks in Utilization of Solid Domestic Wastes and Construction Waste
}

\author{
Victoria Polyakova ${ }^{1}$, Evgeniy Degaev $^{1 *}$ and Pierre El Haddad ${ }^{2}$ \\ ${ }^{1}$ Moscow State University of Civil Engineering, Yaroslavskoe shosse 26, Moscow, 129337, Russia \\ ${ }^{2}$ Saint-Joseph University, Beirut \\ ${ }^{2}$ Lyon III University, France
}

\begin{abstract}
In their activities, humans produce a large amount of wastes. A sharp increase in consumption resulted in a large volume of solid domestic wastes, which must be combated. All this poses a certain life threat to mankind. However, there is no totally waste-free production. That is why the most effective way of waste disposal should be chosen. That is why it is necessary to choose the most effective way of waste utilization with minimization of environmental and economic risks.
\end{abstract}

\section{Introduction}

Urban population grows every year. In the early $21^{\text {st }}$ century urban population was $20 \%$, but by the end of 2017 it reached $75 \%$.

The main problem of urbanization in Russia is an increase in accumulation of solid domestic wastes (SDW) and construction debris in the cities, which entails emergence of new landfills. In most cases, they are poorly arranged or even unauthorized. All this entails environmental deterioration, namely, pollution of atmosphere, water and soil. Therefore, SDW and construction debris disposal remains a very pressing problem in Russia.

Production and consumption wastes (hereinafter referred to as the wastes) are substances or objects that are generated during production, work performance, services rendering or during consumption, which are removed, intended for removal or subject to removal [1-10].

The amount of SDW per person annually increases by approximately $1-4 \%$ and by $0.2-$ $0.4 \%$ in terms of weight.

\section{Materials and Methods}

To combat SDW disposal the following methods are used: intermediate storage, sorting, composting, thermal methods, recycling, briquetting and burial.

This article considers one of SDW disposal methods in detail - composting, which allows to significantly reduce environmental and economic risks.

\footnotetext{
*Corresponding author: degaev@inbox.ru
} 
Wastes composting is converting organic wastes with the use of microorganisms into a mixture that can be used to improve soil fertility. Composting does not require any additional equipment, which indicates that this process is one of the simplest for waste disposal.

Composting is a natural process. It is performed by organisms (bacteria, fungi, worms, insects) that are in wastes and earth and by feeding substances in the material or each other these organisms contribute to wastes processing.

Bacteria are involved only in primary destruction of material. They are not added to compost. While fungi and worms are added to compost heaps (secondary agents of material decomposition). Fungi bring carbon dioxide to the soil and absorb microbes. Worms process organic substances enabling plants to better digest them [3, 16-19].

Wastes can be composted using various methods: in a compost pile, pit, box or trench. Each of these methods is applied to certain volumes of wastes: for private composting it is better to use a box or compost heap, while for larger volumes it is better to use pits or trenches. Since it looks more aesthetically pleasing and preserves moisture and heat inside, which favorably influences composting [11-15].

\section{Waste storage requirements (by composting method):}

1. Storage place should be shaded;

2. Pit, heap or trench must be located at least $50 \mathrm{~cm}$ from the buildings;

3. There must be a passage around the pit;

4. Drainage must be available.

Compost heap must be stacked as follows: base layer is a basis for material formation. It should consist of large brown materials (branches, for example). It is required for good ventilation of stored wastes. This layer must be from 10 to $20 \mathrm{~cm}$ thick. The main layer consists of 2 types of materials mentioned above: nitric and carbonaceous ones. These wastes are stacked separately from each other in layers of $10-15 \mathrm{~cm}$, then they are thoroughly mixed for more active decomposition. Note that materials in the main layer must be finely cut or broken which will also accelerate decomposition process.

Compost heap is mixed and moistened until the compost is ready. This process is best done in summer, since higher temperatures help rapid growth of bacteria and fungi, therefore, compost will be ready sooner. Wastes must be mixed with a shovel or pitchfork for better water provision.

Material readiness can be determined as follows: heap is of dark color; friable consistency; smell of fresh land; it does not look like original materials.

\section{Results and Discussion}

Composting advantages may include: the use of material as recyclables (soil fertilization); waste-free production; landscape improvement; use of this material for additional fertilizing of plants or for mulch. (Mulch is soil covering around plants protecting it from erosion, drying and sun).

Composting difficulties: possibly, heap temperature does not increase (this can be caused by: incorrect heap size (it must be maximum $2 \mathrm{~m}$ wide, $1.2-1.5 \mathrm{~m}$ high); lack of moisture or nitrogen (if a heap is new); poor ventilation); appearance of smell (this problem may be a result of excess water or mush use of green materials); heap attracts animals and insects (do not add wastes with oils, meat or dairy products; if these materials are already in the heap, cover it) [2, 3-7].

\section{Composting technologies.}

Minimal technology. Compost heap is $4 \mathrm{~m}$ high and $6 \mathrm{~m}$ wide. Mixing (turning-over) is performed once a year. Composting process takes 1-3 years depending on climate. This technology requires a large sanitary zone. 
Low-level technology. Compost heaps are $2 \mathrm{~m}$ high and 3-4 m wide. Heaps are mixed more often as compared to minimal technology. The first mixing is in a month, the next mixing is in 10 months. The process itself takes $16-18$ months.

Medium-level technology. Heap is of the same size as with low-level technology. Heaps are turned over daily. Compost can be ready in 4-6 months. The disadvantage of this technology is that capital and current costs are much higher than those of previous technologies.

High-level technology. This technology is similar to the previous one. The only difference is that compost heaps require special aeration. Compost is ready in 2-10 weeks [3].

\section{Solid domestic wastes composting.}

Composting is mainly aimed at disinfecting SDW (in the course of composting wastes heat up to $60-70{ }^{\circ} \mathrm{C}$, which allows to destroy pathogens) and processing into fertilizer. The advantage is that composting releases less greenhouse gases into the atmosphere than burning or landfilling. The main disadvantage of compost is its high content of heavy metals and other toxic substances.

Optimum composting conditions are: pH: 6-8, humidity (W) 40-60\%, composting time is $1-2$ months.

SDW are processed on a small scale of $1-3 \%$ of the total waste amount. This method is widely used in France, Sweden, the Netherlands, Germany, Italy and Spain. Composting is often applied to organic matter extracted from the SDW, which is less contaminated with non-ferrous metals than the rest of the wastes.

In the USSR, a combined (composting and pyrolysis) SDW process plant in the Leningrad region was quite effective. The plant consisted of a number of departments: receiving, biothermal and crushing-sorting one, a warehouse of finished products and pyrolysis unit (for non-compostable part of wastes).

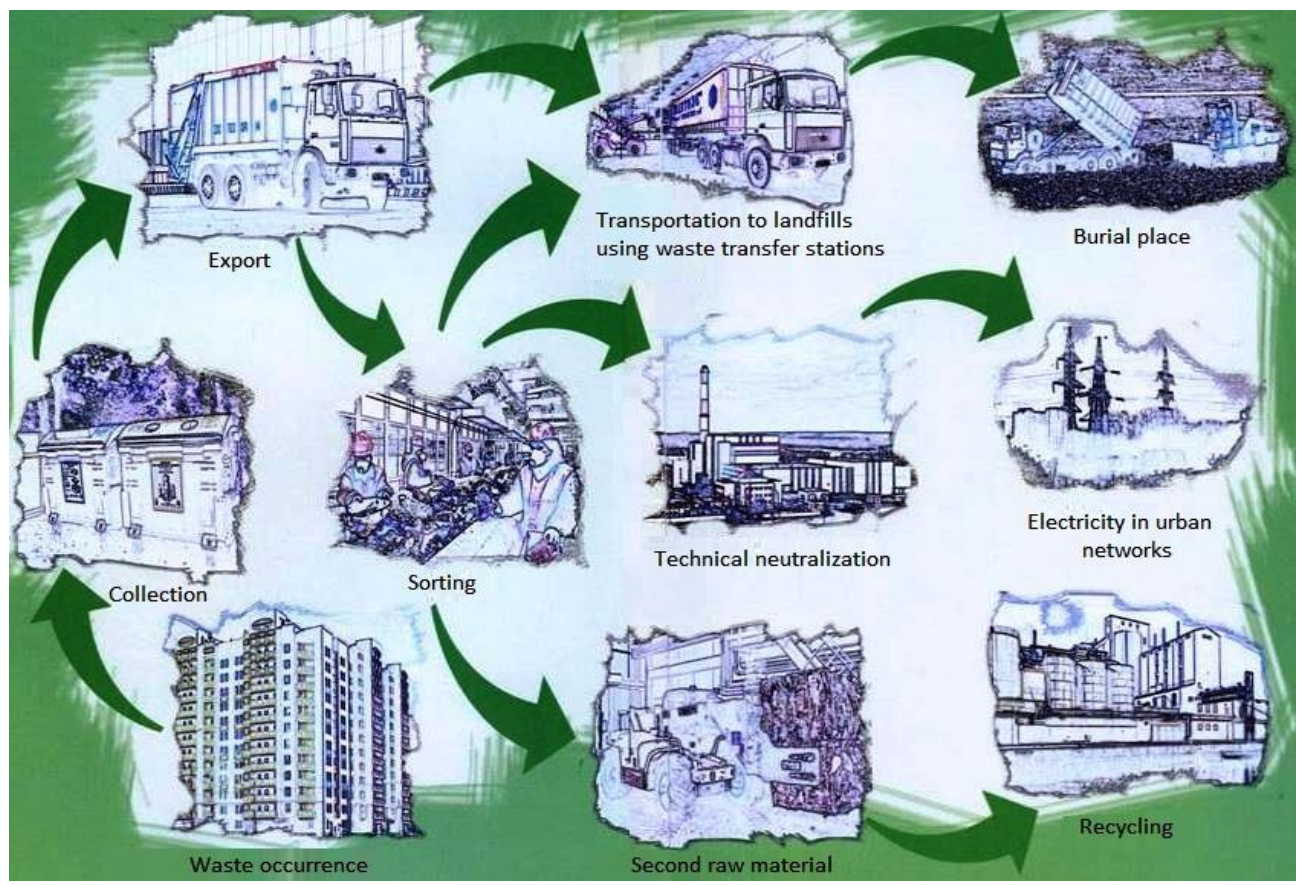

Fig.1. Urban sanitary cleaning diagram 
According to the process diagram (Figure 1), garbage trucks were planned to be unloaded into receiving hoppers, then the wastes are fed to belt conveyors and then to rotating biothermal drums. Waste temperature in the drums increased up to $60{ }^{\circ} \mathrm{C}$ with the help of constantly supplied air. Compost was a loose odorless product. Sifted compost was magnetically separated and sent to crushers for grinding mineral constituents, and then transported to the finished products warehouse. Extracted metal was pressed. Sifted noncompostable part of SDW (leather, rubber, wood, plastic, textiles, etc.) was sent to the pyrolysis unit [5, 20-28].

\section{Conclusions}

It is very unfortunate that recycling industry such as composting is not widely applied in Russia due to unestablished recyclables collecting system, as well as due to absence of places for recyclables collection. The most important thing is that removal system and environmental friendly waste disposal is still not established everywhere. Further ignoring of promising, environmentally and economically sound ways of SDW and construction debris disposal will result in aggravation of already complicated ecological situation in cities. That is why it is necessary to choose the most effective way of waste utilization with minimization of environmental and economic risks.

\section{References}

1. Federal Law. On production and consumption wastes, 89 (1998)

2. L.A. Porozhnyuk, E.V Porozhnyuk, Ecology: educational and practical guide. BSTU Publishing House (2016)

3. Sverguzova S.V., Lupandina N.S., Vasilenko T.A., Olshanskaya L.N. Industrial ecology: educational and practical guide. BSTU Publishing House (2017)

4. B.B. Bobovich, V.V. Devyatkin, Processing of production and consumption wastes, Moscow (2000)

5. A.F. Sharovarnikov, V.P. Molchanov, S.S. Voevoda, S.A. Sharovarnikov, Extinguishing fires of oil and oil products. Izd. house Kalan (2002)

6. V.I. Gorshkov, Extinguishing the flames of flammable liquids. Poznauka (2007)

7. A.H. Baratov, E.N. Ivanov, Firefighting in chemical, petrochemical and petrochemical industries. Chemistry (1971)

8. S.S. Voevoda, V.P. Molchanov, D.L. Bastrikov, M.A. Krutov, Extinguishing fires of motor fuel of the European standard with a low-speed foam. Fire and explosion safety, 20, 4 (2011)

9. D.L. Bastrikov, S.S. Voevoda, V.P. Molchanov, A.F. Shararovnikov, Combined method of extinguishing fires of automobile gasolines in vertical steel tanks. Fire and explosion safety, 23, 6 (2013)

10. D.L. Bastrikov, B.Zh. Bituev, V.P. Molchanov, Application of flexible pipelines in fire protection systems of oil and gas production facilities. Technologies of technospheric security, 58, 6 (2014)

11. V.G. Borkovskaya, E.N. Degaev, I. Burkova, Environmental economic model of risk management and costs in the framework of the quality management system. MATEC Web of Conf., 193, 05027 (2018)

12. Z.M. Xiang, M.L. Guang, L. Chao, Study on Intelligent Fire Fighting System for Large External Floating-roof Tank. International Conference on Intelligent Manufacturing and Materials (2016) 
13. I. Turekova, K. Balog, M. Polka, Effect of firefighting foams on the environment and fire extinguishing. Bezpieczenstwo i Technika Pozarnicza, 25 (2012)

14. D.A. Korolchenko, E.N. Degaev, A.F. Sharovarnikov, Dependence of Fire Extinguishing Efficacy of Low Expansion Foams Solutions Homology Sodium Sulfate on the Molecular Weight of the Surfaceactive Substances. 2nd International conference on material engineering and application (2015)

15. T. Shaefer, B. Dlugogorski, E. Kennedy Sealability Properties of Fluo-rine-Free Fire Fighting Foams. University of Newcastle (2008)

16. V.G. Borkovskaya, Complex models of active control systems at the modern developing enterprises. Advanced Materials Research (2014)

17. V.G. Borkovskaya, Environmental and economic model life cycle of buildings based on the concept of Green Building. Applied Mechanics and Materials (2014)

18. A. Kattge, E.J. Degajev, Der einfluss der höhe der schaumabgabe auf die optimale intensität und den minimalen verbrauch von schaumlöschmitteln. Zeitschrift für Forschung, Technik und Management im Brandschutz, 1 (2016)

19. B.G. Borkovskaya, C.V. Agapov, Standards and fire safety requirements. Fire and Explosion Safety, 11, 23 (2014)

20. E. Degaev, A. Suvorova, A. Suhova, Influence of total head of foam on optimum intensity and minimum particular expense solution size of foamer. IOP Conf. Ser.: Mater. Sci. Eng. 365, 032019 (2018)

21. E. Degaev, V. Razvalyaeva, S. Sabenina, Formation of water film from aqueous film forming foam drops on the surface of oil products. IOP Conf. Ser.: Mater. Sci. Eng. 365, 062037 (2018)

22. Borkovskaya V.G. New requirements professional risks in fire safety. Fire and Explosion Safety, 22, 12 (2013)

23. D.A. Korolchenko, E.N. Degaev, A.F. Sharovarnikov, Determination of the Effectiveness of Extinguishing Foaming Agents in the Laboratory. 2nd International conference on material engineering and application (2015)

24. Degaev E.N. New classification of foaming agents for fire extinguishing. MATEC Web of Conferences 193, 02032 (2018)

25. E.N. Degaev, D.A. Korolchenko, Improving Fire Protection of Pontoon Tanks or Floating Roof Tanks. MATEC Web of Conferences 117, 00036 (2017)

26. E. Korol, N. Shushunova, Green Roofs: Standardization and Quality Control of Processes in Green Construction. MATEC Web of Conferences 106, 06014 (2017)

27. E.A. Korol, S.V. Komissarov, P.B. Kagan, S.G. Arutyunov. The Solution of problems of organizational-technological simulation of building processes. Industrial and civil engineering, 3 (2011)

28. E.A. Korol, A.A. Pleshivtsev, The technology of construction of low-rise buildings from sandwich panels (2017) 